\title{
PEMBANGUNAN JALAN LINGKAR PADANG PARIAMAN DAN PENGARUHNYA TERHADAP PERMASALAHAN KONFLIK PERTANAHAN
}

\begin{abstract}
Afrida $^{1}$
Abstract

This article explain that some problems in societies between individu and groups, groups and groups, and groups and government actors when related white development in rural societies. It is difficult to solve the problem of land because the land owned by groups. The imfact of this condition tend to born of agrarian conflict in societies.
\end{abstract}

Keywords: Development, Agrarian Problems, Conflict, Nagari.

\section{A. Pendahuluan}

embangunan pada dasarnya me rupakan suatu proses yang harus dilalui oleh setiap daerah. Tanpa pembangunan maka suatu masyarakat tidak akan pernah akan mengalami suatu perubahan. Hal ini disebabkan karena pada hakekatnya setiap pembangunan meru pakan suatu proses perubahan yang harus dilalui oleh masyarakat mana pun juga. Apalagi jika masyarakat yang bersangkutan masih berada pada taraf kehidupan yang masih rendah, maka pembangunan merupakan sesuatu yang harus dilakukan. Jika hal itu tidak dilaksanakan maka suatu masyarakat itu tidak pernah akan mencapai sesuatu yang diidamkannya, yaitu ma syarakat yang sejahtera dan makmur.

Hanya saja yang menjadi pokok persoalannya adalah setiap pembangunan yang dilaksanakan mau tidak mau atau suka tidak suka pasti akan membawa dampak terhadap banyak hal yang ada di dalam masyarakat itu. Baik terhadap masalah hubungan sosial di dalam masyarakat maupun terhadap penguasaan aset yang berada di tangan masyarakat itu, seperti tanah dan semua benda yang berada di atasnya. Boleh jadi tanah dimiliki oleh orang lain, tetapi tanaman dan benda-benda lain yang berada di atasnya merupakan milik orang yang berbeda.

Dalam masyarakat Minangkabau, antara kepemilikan dan penguasaan atau pun hak pengelolaan bisa jadi akan berbeda. Tanah bisa saja dimiliki oleh sekelompok orang atau pun serseorang, akan tetapi hak pengelolaan akan dilakukan oleh orang lain dengan berbagai cara. Hal ini bisa jadi berupa pagang gadai atau pun persoalan pinjam meminjam menurut perjanjian tertentu. Masalah seperti ini sering menjadi sumber atau pemicu berbagai persoalan yang akan terjadi kelak di kemudian hari. Persoalan ini akan muncul ketika ada suatu proses yang mungkin timbul dibelakangnya.

Dalam masyarakat Minangkabau tanah bukan lah harta kekayaan yang dimiliki oleh pribadi-pribadi, tetapi tanah adalah harta yang dimiliki oleh sekelompok orang yang punya hubungan darah atau pun hubungan adat istiadat. Hal ini sering muncul dalam pepatah adat yang sampai sekarang masih dihormati oleh sebagian besar anggota masyarakat bahwa harta itu bersifat turun temurun dari satu generasi ke generasi berikutnya. Setiap perpindahan dari satu generasi ke generasi berikutnya

${ }^{1}$ Penulis adalah dosen tetap Jurusan Antropologi FISIP Universitas Andalas 
masalah kepemilikan biasanya akan bertambah jumlah orangnya dan bisa jadi juga akan berkurang. Hal ini di dalam masyarakat Minangkabau dikenal dengan istilah "warih jawek bajawek, dari niniak turun ka mamak, dari mamak tirun ka kamanakan" Artinya setiap perpindahan generasi akan terjadi pula perpindahan hak kepemilikan dan pengelolaan yang akan pada pada dasarnya akan memperluas juga persoalan yang ada di dalamnya.

Hal ini pernah dikatakan oleh A.A. Navis $(1984 ; 150)$ bahwa masyarakat Minangkabau adalah masyarakat agraris dimana tanah dipandang mempunyai posisi yang sangat penting. Dalam falsafah orang Minagkabau, tanah dipandang sangat penting dan merupakan lambang dari martabat suatu kaum. Oleh karena itu, suatu kaum atau pun sekumpulan orang-orang yang tidak memiliki tanah akan dipandang sebagai orang yang kurang dan sering dianggap sebagai orang pendatang (malakok) yang kurang jelas asal usulnya. Tanah merupakan tempat lahir, tempat hidup dan juga tempat mati. Oleh karena itu dapat dikatakan bahwa setiap orang yang hidup harus memiliki sebuah rumah tempat anak cucu lahir dan juga tempat mereka mencari penghidupan, bahkan ketika seseorang meninggal mereka juga masih membutuhkan tanah tempat mereka dikuburkan. Oleh karena begitu pentingnya peranan tanah di dalam kehidupan masyarakat maka akan memunculkan semacam hak dan kewajiban bagi penguasa an tanah yang bersangkutan.

Di dalam masyarakat Minangkabau tanah oleh karena itu bukanlah milik pribadi, tetapi tanah dimiliki sercara bersama di dalam masyarakat. Hal seperti ini di dalam banyak literatur dikatakan bahwa tanah bagi orang Minangkabau merupakan tanah ulayat yang dimiliki oleh sebuah kelompok atau di dalam masyarakat Minangkabau disebut dengan istilah kaum. Tanah oleh karena itu mempunyai status sebagai harta pusaka tinggi yang tidak boleh dipindahkan kepada pihak lain, kecuali melalui suatu permufakatan bersama.

Walau pun secara prinsip tanah menpunyai status sebagai harta pusaka tinggi yang tidak bisa dipindah tangan kan tetapi di dalam praktek sehari hal ini bisa saja terjadi semacam penyimpanganpenyimpangan, baik karena unsur kesengajaan atau pun karena sebab-sebab lain yang tidak disengaja. Artinya sering terjadi karena proses yang tergesa-gesa atau pun karena desakan dari kepentingan lain yang memerlukan proses yang lebih cepat.

Kepentingan pembangunan meru pakan salah satu faktor pemicu terjadinya konflik pertanahan yang terjadi Pembangunan jalan lingkar Kabupaten Padang Pariaman yang melintas dari daerah Buayan Kecamatan Batang Anai yang bermuara di Sicincin, Kecamatan $2 \times 11$ Enam Lingkung, yang pada dasar juga melewati daerah perbatasan antara daerah Sicincin dengan daerah Kepala Hilalang Kecamatan 2 x 11 masalah tanah yang pada dasarnya merupakan tanah ulayat kaum/suku tertentu. Dalam proses pembebasan ini sering terjadi berbagai kendala berhubungan dengan status tanah yang dilewati oleh pembangunan jalan ini Untuk bisa mendapatkan ganti rugi (ganti untung) dibutuhkan surat-menyurat tanah sebagai syarat administrasinya.

Untuk pengurusan surat menyurat dalam arti tanah harus didaftarkan ke Badan Pertanahan Nasional untuk mendapatkan sertifikat. Di sini mulai muncul persoalan berhubungan dengan status tanah sebagai tanah komunal//tanah ulayat Kaum. Permasalahannya atas nama siapa tanah harus didaftarkan. Atas nama penghulu kaum atau atas nama mamak kepala waris atau atas nama pribadi. Hal ini sangat penting karena kalau atas nama Penghulu Kaum penghulu yang bersangkutan justru tidak punya hak atas penguasaan tanah 
tersebut. Kalau atas nama mamak kepala waris ada potensi mamak yang bersangkutan lah yang akan menerima uang ganti rugi, sehingga kemenakan-kemenakan juga berpotensi untuk dirugikan, Kalau atas nama pribadi ini juga dapat merugikan saudara-saudara mereka.

Dalam masyarakat Minangkabau ada mekanisme tertentu yang harus dilewati sebelum hak atas tanah dipindahkan ke pihak lain, salah satunya adalah harus ada kesepakatan yang bulat dari para ahli waris. Artinya ada syarat-syarat tertentu yang harus dilewati supaya tanah dan harta kekayaan lain dapat dipindahkan kepada pihak lain. Disamping itu, karena hal ini tidak saja menyangkut masalah perseorangan tetapi cenderung juga akan melibatkan kelompok-kelompok tertentu di dalam masyarakat nagari.

Dalam keadaan seperti ini, maka dalam proses pembebasan dan pengurusan surat menyurat sebagai syarat administrasi juga akan melibatkan walinagari sebagai fasilitatornya. Walinagari bertindak sebagai penghubung dan perantara dalam proses ini. Oleh karena itu segala yang berhubungan dengan proses akan ditengahi oleh pihak pemerintahan nagari dengan perangkat-perangkatnya.

Dalam masyarakat nagari disamping ada harta kaum dan harta pribadi juga akan melibatkan harta kekayaan nagari. Harta ini dapat berupa material maupun yang immaterial yang dianggap mempunyai nilai. Masalah unuversal yang harus dihadapi masyarakat adalah bagaimana mengatur hubungan antara objek yang ada (Benda Beckmann (2000:37).

Hal yang paling penting dari semua proses ini adalah dalam masalah pemindahan atau pelepasan hak dari masyarakat kepada pihak pemerintah supaya proses pembangunan jalan lingkar itu di mulai. Dari data awal yang di dapat dan sumber ini cukup terpecaya,proses pembebasan tanah atau pelepasan hak dari masyarakat berjalan cukup lama. Proses pendataan sampai kepada proses pelepasan hak sudah dimulai semenjak tahun 2009 dan baru selesai pada pertengahan tahun 2014. Suatu proses yang cukup lama yang banyak menelan waktu dan tenaga. Oleh karena itu masalah ini sangat penting untuk diteliti mengapa begitu lama waktu yang dibutuhkan. Dengan keadaan seperti ini hampir saja mengalami jalan buntu dan cenderung mengancam keberadaan proyek ini kalau saja tidak ditemukan jalan keluarnya.

\section{B. Permasalahan}

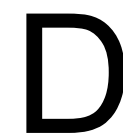
alam masyarakat Minangkabau ada mekanisme tertentu yang sudah digariskan dalam tataran adat.bahwa ada syarat-syarat tertentu yang sudah digariskan dimana tanah atau pusaka hanya dapat dialihkan kepada pihak lain kalau ada hal yang empat, yaitu; rumah gadang keterisan, gadis gadang indak balaki, mayat terbujur di tengah rumah. Anak raja kepanasan. Walaupun sudah ada aturan untuk syarat pelepasan hak tetapi masih terjadi banyak penyimpanganpenyimpangan di dalam praktek sehari-hari.

Banyak pertanyaan yang dapat dilontarkan sehubungan dengan permasalahan ini, namun yang dianggap penting dan berhubungan dengan topik ini adalah:

1. Bagaimana status kepemilikan tanah yang ada di daerah penelitian?

2. Apa hubungan status tanah dengan orang yang mengelolanya?

3. Apakah ada persoalan atau masalah dalam proses pengelolaan ini?

4. Kalau ada bagaimana proses penyelesaiannya? 
5. Berhubungan dengan proses pembangunan jalan lingkar bagaimana cara pemindahan hak dari masyarakat kepada pihak pemerintah?

6. Siapa saja yang terlibat dalam proses pembebasan itu?

\section{Kerangka Konsep}

$\mathrm{K}$ ehidupan sosial akan menyangkut banyak kelompok yang saling berinteraksi, mereka selalu berjuang dalam memperebutkan sumber daya yang tersedia bagi mereka sebagai imbalan dari suatu kegiatan tertentu. Imbalan itu dapat berupa kekayaan, harga diri atau prestise dan juga kekuasaan tertentu.

Dalam kehidupan masyarakat terdapat suatu kekuasaan dan wewenang akan suatu objek tertentu. Menurut Dahrendof (Ritzer, 2003:260), kekuasan dan wewenang selalu menempatkan individu pada posisi atas dan posisi bawah di dalam setiap struktur, karena wewenang itu adalah sah, maka setiap individu yang tidak tunduk terhadap wewenang tertentu akan kena sangsi. Masyarakat memiliki pandangan-pandangan atau perspektif yang berbeda tentang kehidupan dan masalahmasalah yang mereka hadapi dan mereka jalani. Masing-masing individu akan memiliki masalah, karakter dan pandangan yang unik satu sama lain.

Menurut Ritzer, konflik sering terjadi karena dalam pemecahan masalah yang diambil oleh suatu pihak telah merugikan pihak lain atau konflik akan terjadi karena adanya penyimpangan terhadap sistem tradisional yang tidak bisa ditolerir lagi. Disamping ada pihak yang memaksakan untuk menerapkan sistem tradisional. Kalau terjadi konflik maka harus diusahakan untuk mencari penyelesaiannya, sehingga ma syarakat tetap dalam keadaan normal, sebagai suatu sistem yang seimbang (Ritzer, 1992:30).
Konflik adalah hubungan antara dua pihak atau lebih (indvidu atau kelompok yang memiliki atau merasa memiliki sasaran yang tidak sejalan (Fisher, 2001:8). Sedangkan menurut Soekanto, konflik adalah suatu proses sosial di mana orang perseorangan atau kelompok manusia berusaha memenuhi tujuannya dengan jalan menentang pihak lawan dengan ancaman atau dengan kekerasan (1975:220). Dari kenyatan di atas jelaslah bahwa pada dasarnya konflik merupakan suatu gejala yang tidak bisa dipisahkan di dalam kehidapan masyarakat yang pada akhirnya akan memberikan sumbangan terhadap disintegrasi dan perubahan sosial. Dalam tataran masyarakat Minangkabau konflik sering ditemukan di dalam mayasarakat nagari yang dikenal dengan konflik agraria, konflik tersebut dapat terjadi antara satu keluarga atau kekerabatan, atau antara satu desa dengan desa lain, atau yang dikenal juga dengan konflik internal (Afrizal, 2006:2)

Konflik agraria biasa terjadi karena masyarakat nagari atau komunitas menuntut hak-hak ulayat mereka terhadap suatu wilayah atau daerah atau tanah tertentu, aksi demikian biasanya dilakukan oleh masyarakat nagari tersebut karena rasa ketidak puasan terhadap hak-hak yang mereka terima di atas hak ulalayat mereka. Lembaga nagari yang berwewenang di Minangkabau memang dirancang untuk menyelesaikan berbagai sengketa yana ada, apa pun permasalahannya, dilakukan melalui perundingan atau tawar menawar di antara orang-orang yang terlibat sampai kepada dicapainya permufakatan sebagai suatu bentuk penyelesaian yang ideal (Benda-Beckmann, 2000:41)

Apabila lembaga tersebut tidak dapat berfungsi dengan baik, maka diperlukan cara pengendalian yang lain, yaitu mediasi. Mediasi adalah cara pengendalian dimana kedua belah pihak yang bersengketa secara bersama-sama sepakat untuk menunjuk pihak ke tiga yang 
akan memberikan nasehat-nasehatnya bagaimana mereka sebaiknya menye lesaikan sengketa mereka. Mediasi bisa dilakukan oleh seorang aktor atau sebuah lembaga selama mampu menjadi penengah yang netral (Nasikun, 1995:24)

Dalam penyelesaian masalah perta nahan sehubungan dengan dibangunnya jalan lingkar ini memang banyak sekali terjadi semacam ketidak puasan diantara anggota masyarakat dan anggota masya rakat dengan pihak pemerintah daerah yang menangani proyek ini. Karena banyaknya sengketa yang terjadi; sering menghambat dari kelancaran pengerjaan proyek jalan lingkar Padang Pariaman ini. Dengan banyaknya permasalahan yang ada sering proyek ini berjalan lambat dan terhenti. Dengan keadaan yang demikian sampai sekarang proyek tersebut masih berjalan tertatih-tatih; Oleh karena itu penelitian kenapa proyek ini berjalan lambat maka perlu dilihat dan perllu dilakukan semacam penelitian untuk melihak permasalahan apa saja yang ada

\section{Pembahasan}

$\mathrm{P}$ embangunan pada dasarnya merupakan suatu proses perubahan yang direncanakan. Dalam proses ini selalu membawa dampak kepada apa yang menjadi sasaran dari pembangunan itu. Sebagai proses yang direncanakan hasil pembangunan yang diharapkan adalah sesuatu kondisi masyarakat yang lebih baik dari yang ada sebelumnya. Artinya pembangunan merupakan sesuatu yang positif bagi masyarakat dan diharapkan membawa masyarakat yang bersangkutan kepada situasi yang lebih baik dari kondisi sebelumnya. Oleh karena itu masyarakat yang bersangkutan akan mendapat berkah dan keuntungan, salah satunya akibat pembangunan itu sektor ekonomi masyarakat akan berkembang dan meningkat. Akan tetapi pembangunan pada dasarnya juga dapat membawa penga ruhnya yang sebaliknya. Di satu segi perekonomian masyarakat berkembang dengan pesat dan kebaikan-kebaikan lain akan didapat, tetapi di segi yang lain ada hal yang tidak diharapkan akan muncul. Pembangaunan pada dasarnya juga akan cendrung akan memicu semakin tingginya tingkat persaingan di dalam masyarakat dan hal ini bermuara kepada munculnya konflikkonflik tertentu.

Peneltian ini difokuskan di Dusun Sungai Sadah yang terletak dalam Kenagarian Kapala Hilalang Kecamatan 2 x 11 Kayu Tanam. Dusun ini terletak di ketinggian 144 meter $\mathrm{d}$ atas permukaan laut dengan suhu udara berkisar antara 21 derajat sampai 28 derajat dan curah hujan rata-rata pertahunnya $367 \mathrm{~mm}$. Kebanyakan tanahnya bewarna hitam kecuali di bagian Timur yang terdiri dari daerah perbukitan yang tanahnya berwarrna kuning. Jumlah penduduk dusun ini tidak banyak, dari 1976 KK yang ada di Kepala Hilalang hanya sekitar $20 \mathrm{KK}$ yang bertempat di sini. Jumlah penduduk laki-laki dan perempuan di nagari ini relatif seimbang, yaitu 3.955 laki-laki dan 3.739 perempuan.

Kebanyakan penduduk yang tinggal di dusun ini bertumpu pada sektor pertanian dan perkebunan sebagai mata pencarian pokok mereka. Kebanyakan masyarakatnya hidup sebagai petani dan buruh sebagai mata pencarian utama. Bagi yang tidak punya lahan biasanya hidup sebagai penambang batu dan pasir disungai, sopir dan hampir tidak ada yang bekerja sebagai pegawai negeri. Sebagai mata pencarian tambahan ada diantara mereka yang berjualan secara kecil-kecilan di depan rumah mereka dan bekerja di kandang orang lain sebagai buruh kandang. Kandang ayam ini kebanyakan di miliki oleh orang luar yang membuka usahanya di dusun ini. 
Hal ini disebabkan harga sewa tanah di daerah ini masih tergolong rendah dan upah buruhnya masih murah.

Sebelum terbuka akses kendaraan bermotor kondisi dusun cukup mempriha tinkan. Tidak banyak aktifitas yang dapat dilakukan masyarakat kecuali ke sawah sebagai petani dan menderek karet di hutan. Akses jalan baru ada sekitar akhir tahun 80an dimana masyarakat secara swadaya berusaha membangun jembatan dan membuka jalan baru ke dusun ini. Dengan adanya jembatan dan dibukanya jalan baru dusun ini dapat melepaskan diri dari keterisollirannya. Pembukaan jalan ini cukup membawa pengaruh terhadap ekonomi dan pendapatan masyarakat. Dusun ini yang sebelumnya tergolong dusun miskin lambat laun mulai bangkit. Ekonomi masyarakat mulai bangkit dan menggeliat dan wajah dusun mulai berubah sehingga wajah Sungai Sadah yang semula kusam mulai tampak berseri. Anak-anak mulai sekolah dan perdagangan mulai menampakan ronanya.

Pada awalnya tidak banyak permasalahan yang terjadi di dusun ini. Kehidupan masyarakat tampak berjalan sebagaimana mestinya dan seolah-olah tidak ada permasalahan yang terjadi diantara mereka. Mereka hidup damai, saling tegur sapa dan bergotong royong jika ada hajatan seperti pesta perkawinan, acara kematian dan kemasyaratan lainnya. Mereka juga saling tegur sapa jika bertemu di jalan atau kebetulan lewat di depan warung. Jika ada persoalan dan selisih paham yang terjadi diantara mereka segera diselesaikan dengan musyawarah. Pokok nya mereka berusaha menjaga hubungan di antara mereka berjalan dengan baik.

Sebetulnya di daerah ini dan umumnya di nagari manapun di daerah Minangkabau masyarakatnya mempunyai hubungan social yang relatif sulit untuk ditelusuri, entah itu nenek-nenek mereka atau kakek-kakek, paman atau eteknya dan mungkin saja dirinya sendiri ada hubungan dengan individu anggota masyarakat yang lain. Hubungan itu dapat berupa hubungan keturunan atau hubungan lain yang tidak ada sangkut paut dengan keturunan seperti hubungan budi. Karena pada masa lalu nenek atau kakek mereka berteman baik dan banyak jasa mereka yang masih berbekas. Mungkin saja pada lalu karena hubungan pertemanan ini mereka saling memberi. Kebetulan mungkin dia punya tanah yang luas, maka karena ada budi baik yang diterima, dia memberikan sebidang tanah sebagai ucapan terima kasih.

Kebiasan dalam menjaga hubungan baik ini sebetulnya sudah lama berurat berakar di dalam masyarakat di pedesaan. Hal ini punya sejarah yang panjang dan selalu ada cerita dan mitos yang menyokong. Kalau ada persoalan di antara anggota masyarakat, cerita dan mitos ini biasanya juga dibahas. Tentu saja ada tetua (urang tuo) di kampung itu yang terlibat, biasanya terdiri dari orang yang sudah berumur dan punya pengetahuan yang banyak tentang sejarah kampung dan hubungan diantara penduduknya.

Masyarakat tidak bersifat statis, masyarakat bersifat dinamis, setiap saat ada perubahan-perubahan yang terjadi. Banyak generasi baru yang lahir, sebaliknya juga banyak generasi tua yang meninggal. Meninggalnya generasi tua ini tentu saja ada cerita dan mitos-mitos yang hilang, karena mungkin belum sempat diceritakan kepada generasi mudanya, atau generasi tua lupa untuk mencatat. Dengan demikian ada cerita-cerita yang hilang tentang asal dan hubungan masyarakat satu sama lain atau hubungan antara satu suku dengan suku lain.

Berkurangnya jumlah orang tua yang punya pengetahuan tentang sejarah dusun atau kampung punya pengaruah kepada hubungan masyarakat dan asal usul suku dan kekayaannya. Banyak anggota masyakat tidak tahu lagi dari mana mereka 
berasal dan dari mana mereka memperoleh harta kekayaannya, seperti tanah. Tentu saja hal ini dapat membawa pengaruh terhadap hubungan social di dalam masyarakat itu. Kenyataan seperti ini merupakan sesuatu yang cukup berbahaya bagi masyarakat itu sendiri. Hilangnya cerita dan mitos-mitos berarti mereka kehilangan tentang sejarah. Walau pun cerita dan mitos-mitos itu sangat diragukan kebenaranya, tetapi sebagian masyarakat sangat mempercayainya dan mampu meredam konflik yang terjadi.

Demikianlah pada masa lalu, masa sebelum adanya pembangunan jalan lingkar Kabupaten Padang Pariaman dusun ini relatif tenang. Masyarakatnya relatif hidup bersahaja, tidak banyak konflik yang muncul ke permukaan. Kalau pun ada, konflik itu cepat diselesaikan oleh para orang tua dan pemimpin masyarakat. Dengan begitu jarang yang muncul ke permukaan.

Pada pertengahan tahun 2008 ada renncana pemerintahan daerah Kabupaten Padang Pariaman untuk membangun jalan lingkar. Rencana ini sejalan dengan rencana pemindahan ibu kota kabupaten dari Pariaman ke daerah lain. Hal ini disebabkan karena berubahnya status Pariaman dari ibukota kabupaten menjadi kota yang berdiri sendiri. Sebagai konsekwensinya ibukota kabupaten harus dipindahkan ke luar Kota Pariaman. Setelah melalui pengkajian yang cukup lama maka diputuskanlah bahwa ibukota Kabupaten Padang Pariaman diipindahkan ke Parit Malintang.

Daerah yang dijadikan ibukota kabupaten ini termasuk ke dalam dusun Rimbo Kalam. Sesuai dengan namanya Dusun Rimbo Kalam yang berarti hutan yang gelap atau hutan yang masih perawan, tidak banyak akses jalan untuk mencapai daerah tersebut. Satu-satunya jalan yang ada hanya melalui Korong Pasar Dama. Dengan keadaan yang seperti ini tentu keadaan ini akan menyulitkan bagi anggota masyarakat untuk mencapainya. Supaya memudahkankan dan memperlancar anggo ta masyarakat berurusan ke kabupaten maka jalan baru harus di bangun. Pembangunan ini kemudian mendapat respon dari Pemerintahan Propinsi dan Pemerintah Pusat. Hal ini disebabkan karena sering terjadinya kemacetan jalan penghubung Kota Padang dan Kota Bukittinggi terutama di Lubuk Alung dan Sicincin. Disamping kedua permasalahan di atas, beroperasinya Bandara Internasional Minangkabau (BIM) juga menjadi per timbangan penting. Sebagai Bandar Udara Internasional haruslah memiliki dan didukung oleh prasarana transportasi yang memadai.

Banyaknya faktor yang menjadi bahan pertimbangan pemerintah maka pada tahun 2008 pemerintahan Kabupeten Padang Pariaman berusaha keras untuk memulai proyek besar ini dengan cara membebaskan lahan masyarakat dengan cara ganti rugi (ganti untung). Pertemuan awal dimulai pada tingkat pemerintah antara bupati sebagai kepala daerah dengan jajaran terkait, diantaranya; Kapolres, Dandim, Camat dan para Walinagari sekabupaten. Masing-masingn instansi akan bertanggung jawab sesuai dengan fungsinya masing-masing. Walinagari, khususnya akan bertanggung jawab secara langsung dilapangan. Terutama walinagari yang daerahnya akan dilewati oleh proyek.

Para walinagari bertugas secara langsung untuk memberitahu warganya bahwa daerah mereka akan dilewati oleh proyek jalan. Mereka harus memberi penjelasan tentang maksud dan tujuan dari pembangunan serta manfaat-manfaat dari pembangunan jalan baru tersebut. Penjelasan iti meliputi manfaat jalan secara umum, kemudian manfaat jalan bagi kelancaran ekonomi masyarakat, 
pembangunan daerah, dan manfaatmanfaat lain dari dibukanya jalan baru ini. Dalam pertemuan itu masyarakat diminta kesediaannya untuk merelakan tanah dan tanaman mereka apabila terkena dengan proyek ini.

Penyerahan dari tanah dan tanaman merupakan bentuk partisipasi yang diharapkan, karena memang manfaat yang utama dari jalan ini akan dirasakan oleh masyarakat itu sendiri. Terutama bagi masyarakat yang punya kebun dan sawah yang berlokasi dekat jalan. Kalau sebelum adanya jalan masyarakat merasa kesulitan untuk mengangkut hasil pertanian mereka ke pasar, tetapi dengan adanmya pembanghunan jalan ini, maka masyakat akan lebih mudah untuk mengangkut dan memasarkan hasil pertanian mereka. Disamping itu, tanah yang sebelum adanya jalan akan dihargai rendah oleh pembeli, dengan adanya pembangunan jalan baru itu, harga tanah akan melonjak. Demikian diantara materi penyuluhan atau sosilisasi pembangunan dan manfaat jalan bagi masyarakat yang disampaikan oleh walinagari beserta camat. Terutama bagi walinagari yang daerah secara langsung akan terkena proyek pe3mbangunan ini.

Setelah sosialisasi maka langkah berikut yang dilakukan adalah pendataan lahan yang akan dilalui oleh proyek dan tanaman apa saja yang diganti. Dalam tahap ini kemudian dijelaskan tanaman apa saja yang di ganti rugi, diantaranya ada;lah tanaman yang secara ekonomi mempunyai nilai dan hasil dapat memberikan hasil yang laku dijual di pasaran. Masing-masing tanaman ini mempunyai harga dan ganti rugi yang berbeda. Durian sebagai tanaman yang punya arti dan nilai tinggi diganti 75 ribu rupiah, kelapa diganti 75 ribu rupiah. Pinang 25 ribu, pohon karet 15 ribu dan pisang 5 ribu rupiah. Tanaman lain yang tidak mempunyai arti ekonomi tidak mendapatkan ganti rugi. Sedangkan tanah sebagai tempat tumbuhnya tidak mendapatkan ganti rugi, masyaraklah harus melepaskan haknya secara suka rela kecuali tanah berupa lahan persawahan mendapatkan ganti rugi 25 ribu rupiah permeter bujursangkar.

Semua yang terkena pembebasan ini harus dicatat, masing-masing anggota masyarakat yang terkena proyek diberi kebabasan untuk menebang atau memindahan kan tanaman mereka atau menjualnya kepada pihak lain. Pohon durian misalnya, setelah dicatat untuk mendapatkan ganti rugi, anggota masyarakat diberi kebebasan untuk menebangnya dan mengambil kayunya atau menjualnya kapada pihak lain yang membutuhkan. Artinya, pihak pemerintah akan membayarkan ganti rugi tetapi tidak berhak menjual atau memanfaatkan tanaman itu. Anggota masyarakat boleh menjualnya kepada siapa saja yang yang disukainya, sedangkan pihak pemerintah hanya butuh lahan atau tanahnya saja. Dengan cara seperti ini masyarakat mendapatkan dua manfaat, yaiti dapat ganti rugi dari pemerintah dan mendapatkan uang dari tanaman yang dijual kepada pembeli.

Semua proses ini dilakukan melalui proses administrasi, anggota masyarakat diwajibkan mengisi blangko surat pernyataan yang berisi tentang ganti rugi tanaman dan pernyataan tentang pelepasan hak kepada pemerintah dan pernyataan untuk tidak menuntut hak di kemudian hari. Semua proses ini harus melalui proses yang ketat dan disertai bukti kepemilikan yang dikuatkan dengan saksi-saksi dan diketahui oleh walinagari dan camat setempat. Dalam tahap ini harus pula ada tandatangan mamak kepala waris dan penghulu yang bersangkutan. Selesai membuat pernyataan pelepasan hak para pemilik lahan kemudian di foto satu persatu. Tahap berikutnya pemilik lahan harus menunggu proses pencairan dana dari pemerintah.

Dalam tahap pencairan dana ini kemudian mulai muncul konflik-konflik di 
dalam masyarakat tentang siapa yang berhak menerima dana dan alokasi pembagiannya di dalam keluarga. Banyak di antara pohon-pohon yang diganti rugi itu pada dasarnya tidak jelas kepemilikannya. Tanah adalah harta pusaka tinggi yang diwariusi dari generasi sebelumnya bukan harta yang bersifat pribadi. Harta berupa tanah adalah milik bersama dan akan diwariskan kepada generasi selanjutnya. Semua yang hidup pada masa itu merasa punya hak dan harus mendapatkan bagian dari ganti rugi. Sebatang pohon durian akan mempunyai cerita yang panjang tentang siapa yang menanam pada masa lalu. Kemudian siapa yang merawat dan membersihkan dari belukar. Siapa yang mewarisi setelah itu? Kapada siapa pernah digadaikan? Siapa yang lebih berhak mendapatkan uang ganti rugi itu? Dan banyak siapa-siapa berikutnya.

Dalam proses ini akan dituntut kebijaksanaan dari mamak kepala waris terhadap pembagian serta alokasi uang tersebut. Dalam hal ini akan banyak sekali pertimbangan yang harus dijadikan sebagai patokan. Kalau mamak kepala waris tidak bijaksana tentu akan muncul konflik yang lebih besar yang mungkin saja akan bermuara kepada perpecahan di dalam keluarga. Di sini pula lah sang mamak akan memperlihatkan kepiawaiannya dalam memimpin kemenakan dan pula lah sang mamak untuk mampu menafsirkan pepatah dan petitih adat sebagai pusaka yang harus diamalkan dan sebagai warisan budaya. Seorang mamak harus dapat mengantisipasi permasalahan dan konflik yang ada. Fungsi mamak sebagai penengah dan sebagai hakim bijak haruslah di perlihatkan kepada anggota masyarakat yang lain. Kalau ini tidak terlaksana dengan baik maka makian dan umpatan lah yang harus diterimanya.

Konflik yang terjadi pada proses pembagian uang ganti rugi sering menmbulkan perpecahan dikalangan keluarga. Ketidakjelasan siapa pemilik tanaman yang tumbuh di dalam lahan yang di bebaskan merupakan sumber utama pemicu konflik dan perselisihan. Tanaman yang tumbuh di lahan sebelumnya tidak menjadi perhatian utama. Perhatian lebih banyak tertuju kepada lahan atau tanahnya. Dalam kehidupan masyarakat di daerah ini, tanah atau lahan yang berlokasi jauh dari keramaian biasanya sering diabaikan oleh pemiliknya. Sering yang menggarapnya adalah anggota keluarga yang hidupnya paling miskin. Hal ini bukan tanpa alasan, alasannya sangat sederhana, anggota keluarga yang punya pekerjaan atau jabatan tertentu lebih suka melakukan pekerjaannya di kantor pemerintah atau swasta atau mereka berjualan di pasar. Hasil dari pekerjaan ini lebih banyak dan dapat memenuhi kebutuhannya sehari-hari. Pendapatan dari bekerja di kantor atau berdagang di pasar lebih terhormat dan punya gengsi di mata masyarakat. Sedangkan pekerjaan di ladang atau sawah dianggap lebih rendah sehingga ladang atau sawah sering diabaikan dan pengolahannya sering diberikan kepada orang lain atau anggota keluarga yang tidak punya pekerjaan tetap dan penghidupannya yang paling bawah.

Kebiasaan seperti ini lah yang menjadi pemicu konflik yang utama karena orang yang dianggap punya hak atau pewaris utama sering tidak mengetahui tanaman mana saja yang sudah ada sebelumnya dan mana tanaman yang di tanam oleh orang yang mengolah. Sering dalam pengelolaan lahan dalam proses awalnya tidak pernah diperhitungkan tanam mana saja yang sudah ada dan tanaman mana yang masih baru saja ditanam. Lagi pula pemilik utama atau pewaris utama tidak pernah datang ke lokasi lahan dan tidak pernah melihat tanaman apa saja yang 
tumbuh di lahan itu. Mereka kebanyakan hanya mengetahui dari cerita generasi sebelumnya atau dari cerita orang lain.

Sebagai contohnya dapat dilihat dari keluarga Am (57 tahun). Am sudah merantau semenjak mudanya bersama ibu dan dua orang saudara perempuannya. dan jarang sekali pulang ke kampung halamannya di dusun Sungai Sadah ini.Paman dari saudara Am ini terkenal sebagai orang kaya dan pemilik dari sebagian besar tanah di dusun ini. Sewaktu pamannya masih hidup Am tidak pernah peduli dengan tanah pusaka. Dalam pikirannya waktu itu dia tidak pernah berpikir kalau nantinya justru kalau pamannya meninggal dia akan mewarisi tanah tersebut. Dia tidak pernah mengetahui mana saja batas-batas tanah itu dan apa saaja yang tumbuh di tanah tersebut. Di Rantau Am membuka usaha tempel ban dan jual beli ban mobil. Dengan usahanya itu Am merasa sudah cukup bagus karena dapat menghasilkan banyak uang. Apa yang diinginkannya bisa tercapai dan dia dapat membantu kedua saudara perempuanya. Kedua saudara perempuannya kemudian menikah dengan penduduk setempat. Sama dengan Am, kedua saudaranya ini pun tidak mengetahui secara persis mana saja batasbatas tanah pamannya ini.

Sewaktu Paman Am meninggal dia pulang ke Sungai Sadah untuk menghadiri pemakaman pamannya ini. Di kampung dia tinggal selama lebih kurang satu minggu untuk melaksanakan upacara-upacara kematian Dalam masa satu minggu itu pun dia berusaha untuk mengetahui mana saja harta pusaka pamannya yang berupa tanah dan harta lainnya. Dia cuma ditunjukkan oleh orang tua di kampung itu secara garis besarnya saja. Bersama penghulu kaum atau suku dia dinyatakan sebagai pewaris dari harta pamannya bersama saudara perempuanya. Setelah satu minggu di kampung kemudian dia kembali ke rantau di daerah Jambi tanpa mengetahui dengan rinci apa saja tanaman yang ada atau tumbuh di tanah atau lahan warisan itu. Pengelolaan lahan ini kemudian diserahkan kepada orang lain dengan jalan disewakan atau ada sebagian dengan sistem bagi hasil. Kebanyakan yang menyewa masih terhitung sebagai keluarga. Dengan demikian sewa dan bagi hasil tidak diperhitungkan dengan seksama (awak samo awak). Hal ini lah yang menjadi permasalahan di kemudian hari.

Sewaktu proses pembebasan lahan untuk membangun Jalan lingkar PadangPariaman ini Am pulang kampung untuk mendapatkan ganti rugi tanahnya yang tertkena proyek. Semua pembicaraan diserahkan kepada penghulu kaum dan para pengelola lahan. Masalah administrasi pun dia serahkan kepada penghulu. Sampai kepada tahap proses ini hampir tidak ada masalah. Semua berjalan lancara tanpa kendala yang berarti. Permasalahan muncul ketika uang telah dicairkan dan diserahkan kepada orang berhak menerimanya.

Setelah uang diterima Am timbul masalah dalam pembagian uang Masingmasing punya pendapat yang berbeda-beda tentang siapa saja yang harus menerima uang tersebut. Am punya patokan sendiri dan berhak menentukan siapa saja yang harus mendapat bagian dan alokasi dari masing-masing pihak. Penghulu juga punya pendapat bahwa di berhak menentukan siapa yang mendapat bagian dan berapa jumlahnya. Alasan dari penghulu adalah di samping dia sebagai pemimpin kaum, dia juga adalah sebagai orang yabng mengurus semua administrasi dan surat menyurat lainnya. Penyewa dan pengelola lahan disamping itu juga menuntut bagian karena dia telah menanam tanaman tertentu yang masuk ke dalam tanaman yang di ganti rugi. Sehingga pada saat ini terjadi konflik segi tiga yang sempat memicu ketegangan dan dingin antara masing-masing pihak.

Konflik tentu saja membutuhkan suatu penyelesaiaan Masing-masing pihak 
punya alasan yang cukup kuat untuk dapat menikmati uang ganti rugi itu. Akhirnya kemudian dilakukan lah perundinganperundingan dimana mereka harus terlebih dahulu membicarakan permasalahan tersebut dengan kepala dingin. Dengan mengambil tempat di Surau Kaum maka dilakukan perundingan untuk mencegah konflik tidak meluas. Sebelum diadakan perundingan diberikan berbagai macam syarat dan aturan. Diantara syarat itu adalah perundingan harus dilakukan bertempat di surau kaum sebagai tempat yang netral. Perundingan dilakukan dengan semangat kekeluargaan dan untuk mencegah rusaknya hubungan badunsanak dan men doakan arwah nenek moyang yang dianggap telah berjasa. Terakhir keputusan yang dibuat harus diterima dengan kepala dingin dan harus ditaati oleh masing-masing pihak yang terlibat konflik dan tidak boleh lagi mengungkit-ngungkit permasalahan itu di luar surau.

Hasil dari perundingan dan musyawarah adalah dihasilkan suatu keputusan yang menyatakan bahwa uang hasil ganti rugi harus dibagi tiga. Sepertiga dari uang ganti rugi akan diserahkan kepada saudara Am sebagai pewaris bersama dengan saudaranya yang lain. Sepertiga merupakan pembagian penghulu sebagai mamak kepala waris karena usahanya mengurus surat tanah sebagai syarat untuk mendapatkan ganti rugi dan sisanya sepertiga lagi akan dibagikan kepada dunsanak yang lain dan penggarap sebagai orang yang telah berjasa menjaga dan mengurus tanah pausaka ni selama Am berada di rantau.

Lain kasus Am lain pula kasus $\mathrm{Hn}$ seorang perempuan berumur 44 tahun ini. Yang menjadi sumber konflik bukan saja masalah tanahtetapi juga ada hubungannya dengan masalah harta lainnya. Hn punya sebuah rumah yang didirikan di atas pusaka. Tanah ini memaang sudah diperuntukan bagi $\mathrm{Hn}$. Kira-kira sepuluh tahun sebelum proyek ini ada $\mathrm{Hn}$ menikah dengan seorang laki-laki yang berasal dari luar desa dan telah dianugerahi 4 orang anak. Sewaktu anak pertamanya lahir terniat dalam hatinya untuk membangun sebuah rumah. Dia sudah merasa segan tinggal menumpang di rumah orang tuanya. Niatnya ini disamapaikan kepada suaminya bernama Ms. Ms menyokong niat dan keinginan istrinya dan dilanjutkan kepada orang tuanya. Orang tua $\mathrm{Hn}$ juga setuju dan kemudian dimusywarahkanlah niat ini kepada anggota keluarga yang lain. Hasil dari musyawarah disepakati bahwa $\mathrm{Hn}$ akan diberikan sebidang tanah untuk membangun rumah itu. $\mathrm{Di}$ atas tanah itulah $\mathrm{Hn}$ mendirikan rumah yang merupakan hasil jerihnya payahnya bersama suami tercinta.

Pada saat Proyek Jalan Lingkar ini dibangun rumah $\mathrm{Hn}$ rupanya terkena oleh jalur jalan yang akan dibangun.Kemudian dia dihubungi oleh panitia pembebasa lahan yang diketuai oleh walinagari Sicincin. Berhubung karena rumahnya masih dalam kondisi baru maka ganti ruginya juga akan berbeda dengan rumah yang sudah usang. Pada saat itu dia mendapatkan ganti rugi sekitar Rp.120 juta berhubung rumahnya masih belum punya loteng.

Hasil uang ganti rugi ini kemudian menjadi sumber konflik dengan seorang sepupunya yang laki-laki. Alasan yang dikemukakan waktu itu adalah rumah $\mathrm{Hn}$ didirikan di atas pusaka.Permintaan saudara sepupunya ini kemudian mendapat penolakan dari $\mathrm{Hn}$ dengan alas an bahwa tanah itu sudah diserahkan kepadanya. Dengan demikian tanah itu sudah merupakan haknya bersama anak-anak.

Konflik antara $\mathrm{Hn}$ dengan $\mathrm{Dt}$ berlangsung cukup lama dan sempat menyebabkan hubungan mereka menjadi renggang. Pada satu sisi Dt selalu 
mendesak supaya uang itu dibagi pada sisi yang lain $\mathrm{Hn}$ selalu bertahan dengan pendiriannya bahwa ganti rugi itu adalah haknya karena yang terkena proyek adalah rumahnya sendiri. Lagi pula uang ganti rugi itu akan digunakan untuk kembali membangun rumah.

Konflik yang berlangsung cukup lama ini kemudian mendapat tanggapan dari saudara laki-laki sekandung dengan $\mathrm{Hn}$ yang selama ini merantau di daerah Bengkulu, Saudara sekandung $\mathrm{Hn}$ sebut saja bernama NL. NL kemudian membawa permasalahan ini kepada mamak waris. Setelah melului pembicaraan dan musyawarah yang cukup panjang, akhirnya di dapat suatu keputusan bahwa Dt tidak berhak meminta bagian dari uang ganti rigi ini. Alasannya yang utama adal;ah uang ini akan kembali digunakan untuk membangun rumah sebagai ganti rumah yang terkena proyek. Kalau uang ini dibagi, uang ini tidak mencukupi lagi,karena $\mathrm{Hn}$ harus membeli tanah orang lain untuk bisa membangun kembali rumahnya.

Setelah konflik ini dapat diselesaikan dan Dt tidak jadi meminta bagian dari ganti rugi ini, maka $\mathrm{Hn}$ bersama suaminya kemudian membeli sebidang tanah dari tetangganya seluas 500 meter persegi dari tetangga seharga 50 juta rupiah. Diatas tanah yang dibeli ini kemudian $\mathrm{Hn}$ membangun rumah barunya dan menghabiskan dana sekitar 50 juta rupiah. Hal ini dimungkinkan karena dari rumah yang terkena proyek itu, $\mathrm{Hn}$ masih bisa memanfaatkan kusen-kusen dan kayunya karena masih dalam kondisi yang bagus.Dengan demikian $\mathrm{Hn}$ bisa menghemat pengeluaranya. Sisa uang sebanyak 20 juta rupiah kemudian digunakannya sebagai modal usaha dengan membangun sebuah Heler dengan mesin penggerak mesin mobil diesel bekas mobil truk.

Sebetulnya banyak kasus-kasus konflik yang bersumber dari tanah di daerah ini, kasus-kasus tersebut dimulai atau dipicu oleh kedudukan tanah sebagai pusaka tinggi yang tidak bisa diperjual belikan kalau tidak ada alas an yang cukup kuat.Kasus yang cukup menarik adalah berasal dari keluarga YI dan keluarga Al. Tanah yang menjadi sumber sengketa terletak di seberang sungai dan berbatas dengan jalan raya Padang- Bukittinggi. Pada daerah seberang sungai ini proses pembebasan lahan relative sulit dan banyak memakan waktu. Sehingga menjadi penghalang yang cukup berarti dan membuat proyek mengalami kendala dalam waktu yang cukup lama.

Pada daerah seberang sungai ini ganti ruginya berbeda dengan lokasi dalam, daerah dalam (timur) tanah tidak diganti rugi, tetapi yang diganti adalah tanaman. tetapi di bagian luar (barat) yang dekat dengan jalan raya, masyarakat tidak diganti tanaman. Masyarakat meminta yang diganti adalah lahan pertanian mereka Kebanyakan tanah bagian luar ini terdiri dari areal persawahan dan tanah bagian dalam kebanyakan terdiri dari kebun karet dan peladangan. Dala, posisi yang seperti ini harga cukup mahal dan sangat berharga sekali sehinga ganti rugi harus sebanding dengan harga yang berlaku.

Pembebasan lahan yang dekat jalan raya ini memakan waktu yng cukup lama. Hampir satu tahun waktu yang dibutuhkan. Sebagai mediatornya tidak lagi walinagari Sicincin, tetapi berganti dengan walinagari Kepala Hilalang. Sedangkan dari pihak pemerintah diwakili oleh Dinas Pekerjaan Umum Propinsi dan Dinas Pekerjaan Umum Kabupaten Padang Pariaman, Perundingan demi perundingan dilakukan mulai penawaran dari 50 permeter, 100 ribu permeter, 150 ribu permeter, 250 ribu permeter dan 400 ribu permeter masarakat selalu menolak dan pihak pemerintah sempat mengalami frustasi.Banyak cara yang telah dilakukan dengan berbagai alasan, tetapi selalu ditolak oleh anggota 
masyarakat yang tanahnya terkena jalur proyek ini.

Setelah hampir satu tahun berlalu akhir berlalu, pihak masyarakat menawarkan kepada pemerintah bahwa mereka mau menyerahkan tanah mereka dengan syarat sesuai dengan kesepakatan di antara masyarakat itu. Dari hasil musyawarah masyarakat yang berlangsung di Kantor Walinagari Kepala Hilalang mereka telah memutuskan bahwa harga permeter ganti rugi tanah terdiri dari dua harga. Bagi yang tanahnya berbatasan langsung dengan jalan raya harga yang ditawarkan adalah 600 ribu rupiah permeter persegi dan untuk tanah yang tidak langsung berbatasan dengan jalan raya masyarakat meminta harga 250 ribu rupiah permeternya. Hasil dari musyawarah anggota masyarakat ini yang difasilitasi oleh wali nagari kemudian ditawarkan kepada pihak pemerintah. Setelah melakukan berbagai pertimbangan maka akhirnya pihak pemerintah menyetujuinya dengan syarat bahwa tanah yang diganti rugi dan dicairkan dananya hanya tanah yang disertai dengan bukti kepemilikan yang sah atau tanah/lahan yang punya sertifikat.

Setelah persetujuan dari pemerintah ini maka bersegeralah mereka mengurus sertifikat tanah ini. Pengurusan ini tidak selalu berjalan mulus karena berbagai sebab. Ada diantara pemilik lahan ini tanah yang mau disertikatkan itu masih dalam status tergadai kepada pihak lain dan ada yang anggota keluarganya tidak mau menandatangani surat persetujuan sebelum jelas system pembagian hasil ganti rugi tanah itu. Dalam kondisi ini terjadi dua macam konflik, tidak lagi antara pihak pemerintah dengan masyarakat, tetapi justru antara masyarakat dengan masyarakat dan antara anggota keluarga dari pemilik itu sendiri atau konflik dalam keluarga yang menyangkut alokasi pembagian dari ganti rugi.

Sebagai gambaran dapat dikemukakan keluarga YI sebagai contohnya, YI (43 tahun) adalah seorang laki-laki yang masih muda, dia bersaudara sebanyak lima oaring, terdiri dari dua lakilaki dan tiga perempuan dan saudara perempuannya yang tertua telah meninggal dunia, tetapi didalam keluarganya termasuk orang yang cukup terkemuka karena punya pergaulan yang cukup luas dan pendidikan sekolah menengah. Sebagai laki-laki sebetulnya ada yang lebih berhak dari pada YI yaitu Sm. Sm adalah kakak YI berhubung pendidikannya hanya tamatan sekolah menengah pertama dan juga pergaulannya yang kebanyakan hanya pada kalangan terbatas saja \{kebanyakan petani), maka YI dianggap lebih pandai dan ditunjuk sebagai wakil keluarga oleh saudaranya yang lain.

Dalam perhitungannya di antara keluarga dikemukannya bahwa hasil ganti rugi ini akan dibelikan kembali kepada sebidang tanah sawah untuk pengganti sawah yang terkena proyek. Sebab sawah yang terkena proyek itu merupakan satusatunya sawah warisan dari orang tuanya yang telah meninggal dunia. Dalam pembagian uang hasil ganti ini terjadi semacam ketidakadilan,setelah uang dibagi dua, separonya kemudian dibagi lima. Dalam pembagian ini terjadi ketidakadilan, bagian dari $\mathrm{YI}$ tetap porsinya lebih besar. Masing-masing mendapatkan bagian 200 juta rupiah, sedangkan $\mathrm{YI}$ mendapatkan lebih. Alasan YI mendapatkan lebih karena dia harus mengeluarkan uang untuk pengurusan sertifikat, member orang tertentu, member aparat nagari dan ongkos kesana dan kemarinya. Dengan demikian YI mendapatkan lebih dari pembagian yang lain, lagi pula uang yang separo lagi disimpan di bank juga atas nama $\mathrm{YI}$ sendiri. 
Walau pun banyak protes dari anggota keluarga yang lain namun $\mathrm{YI}$ tetap dalam keputusannya. Banyak kasus yang dijadikan contoh bahwa sering terjadi konflik dalam keluarga dalam proses pembagian uang ganti rugi ini. Meskipun ini tidak langsung berhubungan dengan tanah, tetapi akar penyebabnya tetap bersumber dari hasil penjualan tanah yang nota benenya adalah harta pusaka milik bersama.

Konflik lainnya yang lebih langsung justru terjadi setelah proses pembebasan ini, Setelah tanah selesai diganti rugi, pihak pemerintah kemudian melakukan pembersihan lahan dan kemudian dilanjutkan pemubuatan badan jalan. Selesai badan jalan dibuat, ternyata dampaknya sangat besar sekali terhadap semakin melonjaknya harga tanah di sekitarnya. Tanah yang pada awalnya diamggap tidak begitu dipedulikan kemudian justru berubah menjadi primadona baru yang harganya cukup mengiurkan.

Sebelum adanya proyek jalan lingkar ini untuk medapatkan tanah tidak begitu sulit. Sebagai contohnya, jika seseorang ingin membeli tanah untuk keperluan tertentu cukup memberitahukan kepada penduduk setempat. Dengan sendirinya setelah pemberitahuan ini banyak anggota masyarakatyang menghubungi si calon pembeli dan harganya damai, artinya harganya bisa dinegosiasi sesuai kesanggupan calon pembeli. Patokan harga terendah adalah antara 10 ribu sampai 25 ribu permeter perseginya sebagai harga termahalnya. Namun setelah dibangunnya jalan lingkar ini harga tanah melonjak tajam berkali-kali lipat.

Naiknya harga jual tanah ini kemudian justru berbanding lurus dengan semakin meningkatnya konflik-konflik yang terjadi yang bersumber tanah.Menurut data yang ada dilapangan dahulu sebelun adanya rencana jalan akan dibangun masyarakat mudah saja menyerahkan tanahnya kepada orang lain, baik itu untuk digarap dengan imbalan seadanya dalam arti terserah penggarap mau memberi atau tidak hasil garapannya, sewa menyewa atau pun pagang gadai dengan gampang bisa dilakukan. Untuk proses ini sering tidak diiringi dengan perjanjian dan surat menyurat yang jelas. Bahkan ada orang yang dengan rela memberikan saja tanahnya kepada orang yang sebenarnya tidak berhak menerimanya, seperti memberikan kepada istri atau anak dari pihak laki-laki untuk selamanya karena memang dia tidak mempunyai keturunan perempuan tanpa diiringi dengan persetujuan dari anggota kaum yang lain.

Proses pengalihan hak atas tanah yang tidak disertai dengan proses administrasi dan persetujuan anggota kaum ini kemudian menjadi sumber konflik pada generasi berikutnya. Masyarakat cuma berpatokan pada cerita-cerita kebetulan masih ada dan masih diketahui oleh orangorang tertentu. Dari hampir 300 hektar lahan yang ada di dusun ini, hampir sepertiganya dalam status sengketa. Baik karena urusan pagang gadai maupun urusan garapmengarap dan masalah pemberian. Menurut penduduk setempat konflik pertanahan di dusun ini telah meningkat hampir tiga kali lipat dari kondisi sebelumnya.

\section{E. Kesimpulan Dan Saran}

\section{Kesimpulan.}

$\mathrm{P}$ roses pembangunan yang dilakukan pemerintah pada dasarnya berguna untuk masyarakat karena pada prinsipnya banyak $\mathrm{m}$ anfaat dan keuntungan-keuntungan yang dapat diambil dan dinikmati oleh masyarakat itu sendiri. Diantara keuntungan itu ada yang laungsung bisa digunakan oleh masyarkat seperti jalan dan jembatan dan ada yang tidak langsung sepewrti pembangunan pabrik dan areal perkantoran. 
Disamping bermanfaat bagi masyarakat ternyata pembangunan juga sering menimbulkan masalah sebagai akibat dan akses tidak langsung dari prose situ. Banyak akses yang terjadi pada dasarnya bukanlah bersumber dari pihak pemerintah, tetapi sering pula diakibatkan oleh proses yang terjadi di dalam masyarakat itu sendiri atau akibat dari proses yang terjadi dan kelalain yang dibuat oleh masyarakat itu pada lalu.Akibat dari peristiwa masa lalu itu kemudian dampaknya dirasakan pada saatnya ini.

Konflik yang terjadi di dalam masyarakat bukanlah sepenuhnya merupakan kesalahan pemerintah. Kadangkadang pemerintah telah melakukan suatu pendekatan yang benar namun masyarakat melakukan respon yang salah. Prinsipprinsip ajimumpung masih sering dilakukan oleh orang-orang tertentu. Kekuasan dan kewenangan yang yang diberikan masyarakat sering pula disalahartikan dan digunakan tidak menurut semestinya, sehingga hal ini sering menjadi sumber dari banyak konflik di dalam masyarakat.

Banyak dari pemimpin informal tidak lagi menjalankan fungsinya dengan baik. Seorang mamak yang seharusnya menjadi pelindung dari kemenakannya justru berubah menjadi orang yang bertindak meruigikan dan membodohi kemenakannya. Mamak sering menggunakan kewenangan dan kekuasaannya untuk mendapatkan keuntungan material lebih. Mamak yang seharusnya bertindak untuk mencegah munculnya konflik justru sering berubah menjadi sumber konflik di dalam keluarga. Disamping itu banyak dari kebiasan masyarakat yang tidak terbiuasa dengan proses administrasi dan surat menyurat justru berubah menjadi sumber konflik pada masa datang setelah anggota masyarakat telah meninggal dunia. Konflik itu disebabkan karena pemberian atau penyerahan hak hanya dilakukan melalui mulut saja dan disaksikan oleh orang-orang tertentu. Ketika para saksi telah meninggal dan cerita tentang asal usul harta mulai kabur maka orang sering bertikai terhadap kepemilikan sesuatu seperti tanah tersebut.

\section{Saran}

embangunan pada dasarnya
bertujuan untuk meningkatkan
kesejahteraan masyarakat dan meingkatkan pelayanan pemerintah terhadap rakyat, maka seharus dalam proses pembangunan itu haruslah diperhatikan ndengan baik apa yang dibutuhakan oleh masyarakat bukan apa yang diinginkan pemerintah saja. Dengan demikian keinginan pemerintah harus sejalan apa yang dibutuhkan masyarakat

Disamping itu masyarakat harus dibangkitkan kesadarannya bahwa pembangunan itu berguna bagi mereka dan keturunannya di kemudian hari. Oleh karena itu masyarakat harus didik untuk melakukan sesuatu menurut jalur yang semestinya dan melakukan sesuatu harus disertai dengan bukti yang cukup, sehingga di kemudian hari dapat mengurangi konflik-konflik yang mungkin saja terjadi.

\section{Daftar Pustaka}

Afrizal. Sosiologi Konflik Agraria (proses-proses Agraria dalam masyarakat Indonesia Kotemporer). Padang Andalas University Press, 2006. 
Benda Beckmann,Kebeet Von. Goyahnya Tangga Menuju Mufakat. Jakarta, PT. gramedia Widia Sarana.2000.

Bungin, Burhan. Metodologi Penelitian Kualitatif. Jakarta. PT. Raja Grafindo Persada.2004)

Dahrendof, Ralf. Kelas dan Konflik Kelas dalam Masyarakat Industri. JAKARTA. Rajawali Press. 1987.

Ritzer,George. Sosiologi Ilmu PengetahuN Berparadigma Ganda, Jakarta, PT. Raja Grafindo Persada.2003.

Nasikun. Sistem Sosial Indonesia, Jakarta. PT Raja Grafindo Persada. 1995.

Navis.A.A . Alam Takambang Jadi Guru 